MS. ZOE TZI-HUI LOH (Orcid ID : 0000-0002-9215-1441)

Article type : Breast Images

\title{
Ectopic breast cancer in the inguinal region
}

Zoe Loh, $\mathrm{MD}^{1}$, Belinda Yeo, MBBS MD², David S Williams, MBBS PhD²,

David E Gyorki, MBBS MD ${ }^{1,4,5}$

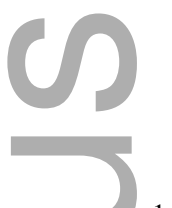

1-3. Department of ${ }^{1}$ Surgery, ${ }^{2}$ Medical Oncology and ${ }^{3}$ Pathology, Austin Health, Heidelberg, Victoria, Australia

4. Division of Cancer Surgery, Peter MacCallum Cancer Centre, Melbourne, Victoria, Australia

5. Department of Surgery, University of Melbourne, Victoria, Australia

\section{Corresponding Author: David E Gyorki}

Address: Department of Surgery, Austin Hospital, PO Box 5555, Heidelberg, Victoria, Australia, 3084

Phone: 0394965000

Email: david.gyorki@petermac.org

Fax:039458 4779

A 47-year-old female with no significant past history presented with a rapidly-enlarging, painful right inguinal mass, extending deep to the labia majora and into the femoral canal (Fig 1). The patient underwent complete resection. Histopathology revealed a wellcircumscribed $65 \mathrm{~mm}$ tumour consisting of poorly differentiated epithelioid cells, and a benign cloquet's node. Immunohistochemical staining showed reactivity to cytokeratin This is the author manuscript accepted for publication and has undergone full peer review but has not been through the copyediting, typesetting, pagination and proofreading process, which may lead to differences between this version and the Version of Record. Please cite this article as doi: $10.1111 /$ tbj.13177

This article is protected by copyright. All rights reserved 
(AE1/3), estrogen receptor (60\%) and progesterone receptor (10\%), but was negative for CK20, WT-1, Pax8, S100 and HER2. Extensive workup with whole body positron emission tomography (FDG-PET), breast tissue biopsy, colonoscopy and transvaginal ultrasound did not identify any sites of primary or metastatic disease.

7 months later the patient presented with a locoregional recurrence. MRI demonstrated a $9 \mathrm{~cm}$ x $8.5 \mathrm{~cm}$ x $8 \mathrm{~cm}$ soft-tissue mass in the same location as the original tumour (Fig 2), and again no evidence of disease elsewhere on FDG-PET. Upon resection, this was found to be a $110 \mathrm{~mm}$ tumour arising within soft tissue with no evidence of pre-existing lymph node. The cells had equivalent morphology to the first tumour with a similar pattern of ER and PR expression. Further staining revealed that cells were positive for GATA3 (Fig 3) and negative for mammaglobin and GCDFP-15. The final interpretation was carcinoma favouring breast differentiation, likely arising from ectopic breast tissue (EBT).

Failure of the embryonic ridge to regress during gestation results in EBT with varying degrees and forms of expression. EBT may thus present anywhere along this milk line, which is known to run from the axilla to the medial groin. Carcinoma arising from ectopic breast tissue (EBT) is rare, with an estimated prevalence of $0.3 \%$ of all breast cancer. Over $90 \%$ of cases occur in the axilla, and less commonly in the vulva and anterior chest wall. EBT in the inguinal region is extremely uncommon. To our knowledge this is the only case of primary breast carcinoma arising from ectopic tissue in the inguinal region of a female patient.

This case presented a diagnostic challenge, given a poorly differentiated tumor with no clear histological subtype. Furthermore, despite having no evidence of metastasis and an upfront resection with negative margins, there was an early and aggressive recurrence. The final diagnosis of ectopic breast carcinoma was made on the basis of hormone receptor and GATA3 positivity in a tumor located along the milk line in the absence of a primary breast or gynaecological tract lesion. Precursor benign breast tissue at the tumor site was not detected, likely to have been obliterated by the large mass.

Following the second resection, the patient received adjuvant treatment as for locally advanced breast cancer, with 4 cycles of doxorubicin $\left(60 \mathrm{mg} / \mathrm{m}^{2}\right)$ and cyclophosphamide $\left(600 \mathrm{mg} / \mathrm{m}^{2}\right)$ chemotherapy, followed by 12 cycles of weekly paclitaxel $\left(80 \mathrm{mg} / \mathrm{m}^{2}\right)$ followed by radiotherapy (60 Gy in 30 fractions). 
This is a rare case of an aggressive EBT carcinoma presenting in an unusual location, and highlights the need to consider the embryology of breast development in identifying unusual tumours located along the milk line.

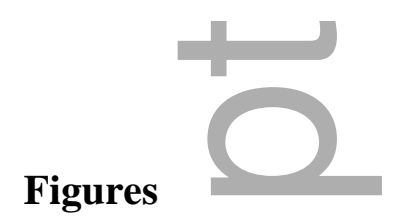

Figure 1: Initial presentation of large right inguinal mass

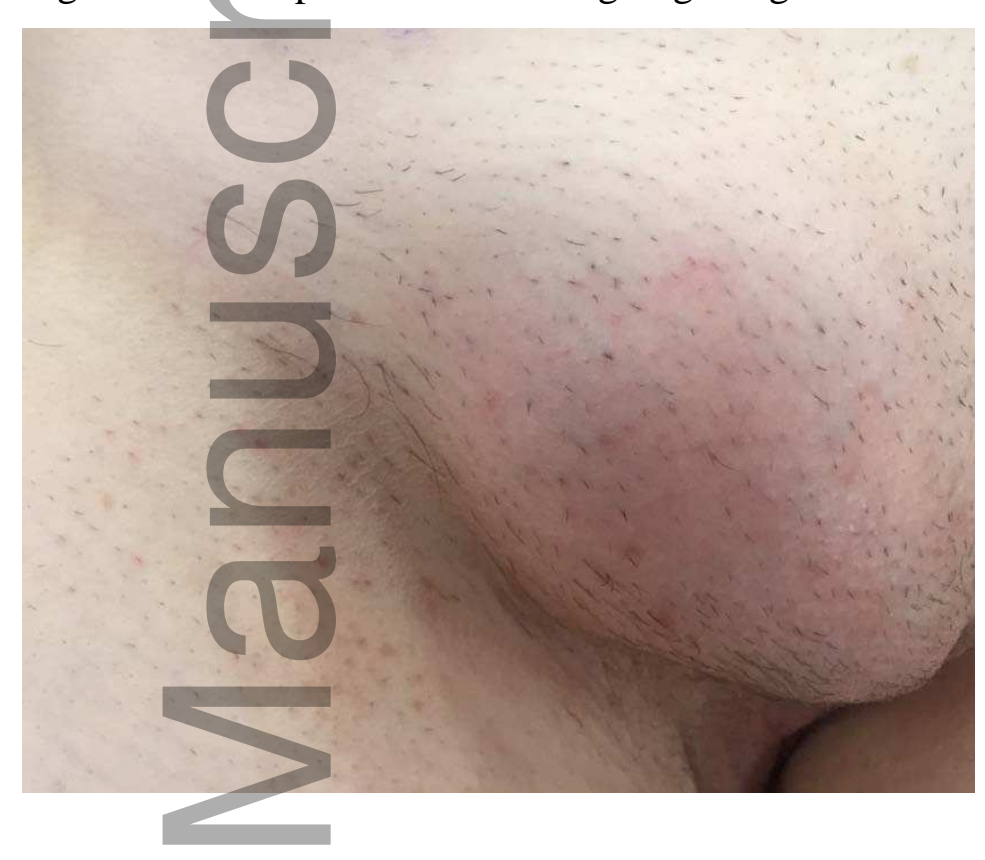

Figure 2: Axial T2 weighted MRI image of large right pelvic mass representing regional recurrence

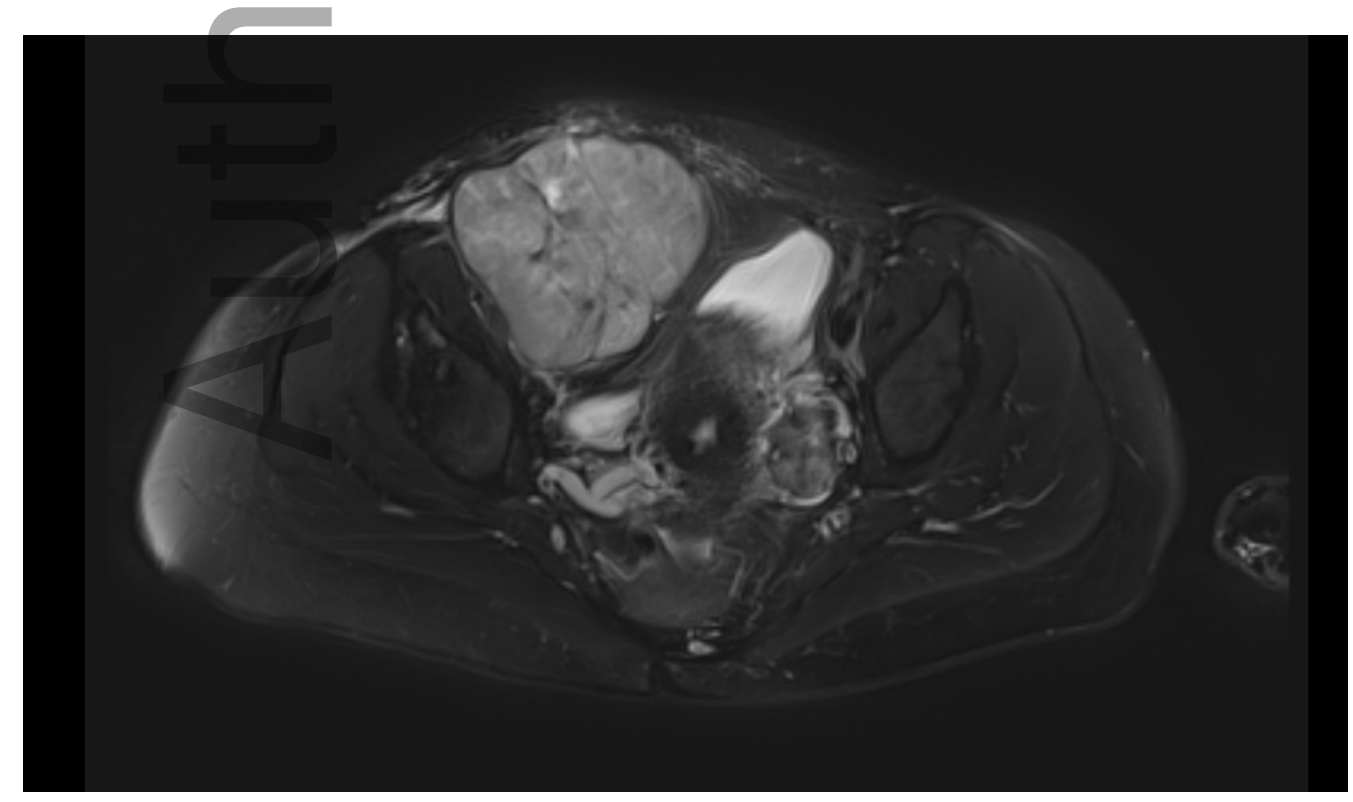

This article is protected by copyright. All rights reserved 
Figure 3: Histological findings of the recurrent mass (x200). Poorly differentiated tumour cells with focal tubule formation on $\mathrm{H} \& \mathrm{E}(\mathrm{A})$. Immunohistochemically positive for estrogen receptor (strong)(B), progesterone receptor (C) and GATA3 (D).
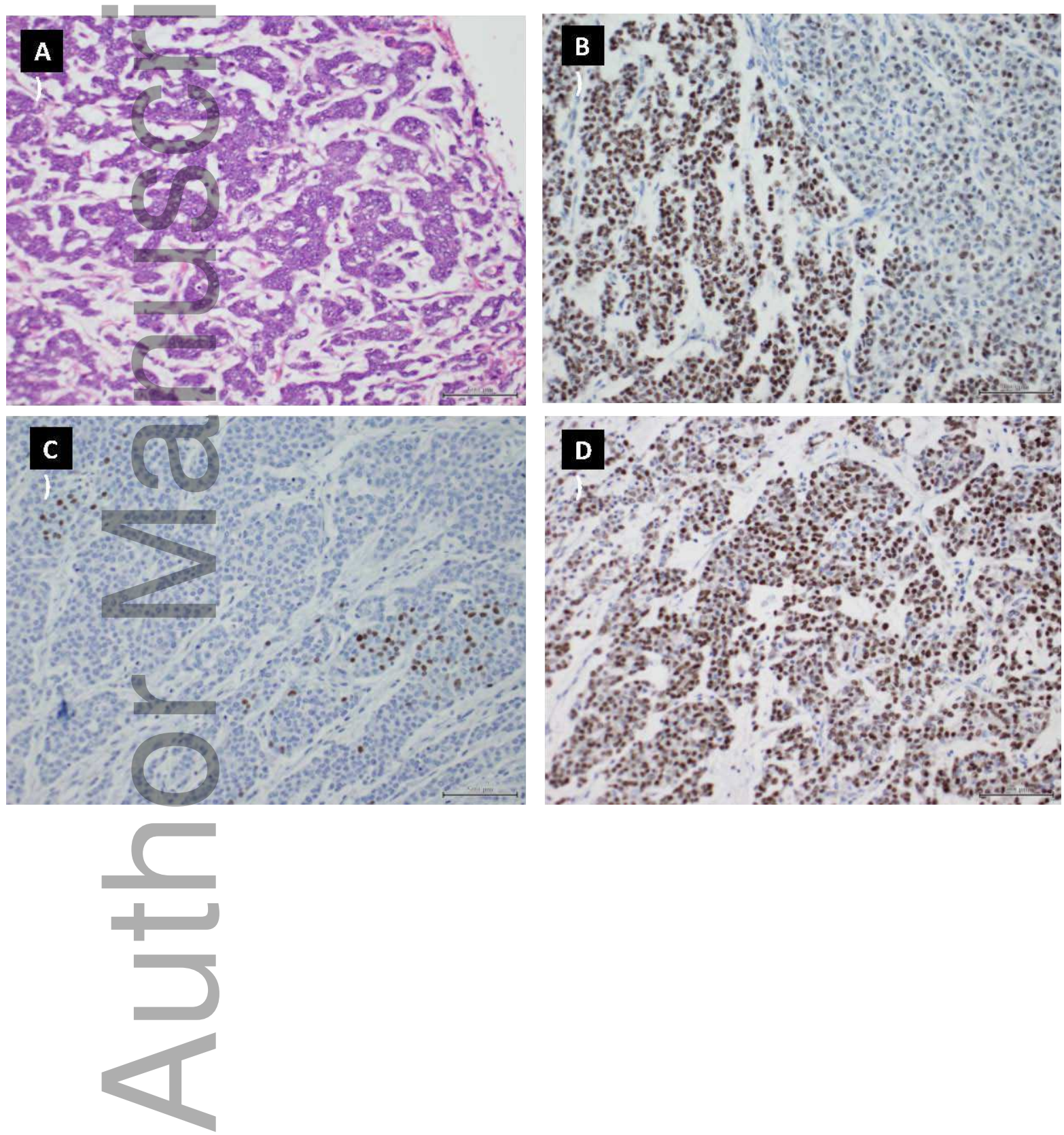


\section{University Library}

\section{- M M I E E R VA A gateway to Melbourne's research publications}

Minerva Access is the Institutional Repository of The University of Melbourne

Author/s:

Loh, Z;Yeo, B;Williams, DS;Gyorki, DE

Title:

Ectopic breast cancer in the inguinal region

Date:

2019-01-01

Citation:

Loh, Z., Yeo, B., Williams, D. S. \& Gyorki, D. E. (2019). Ectopic breast cancer in the inguinal region. BREAST JOURNAL, 25 (1), pp.155-156. https://doi.org/10.1111/tbj.13177.

Persistent Link:

http://hdl.handle.net/11343/285229 